DOI: 10.26693/jmbs04.04.026

UDC 616. 314-002-08-039. 71

Sokolova I. I., Yaroshenko O. G., Oleinichuk V. V.

\title{
SOME ASPECTS OF DENTAL CARIES PREVENTION
}

\author{
Kharkiv National Medical University, Ukraine
}

sokdentirina@gmail.com

\begin{abstract}
Environmental factors play a leading role in the incidence of caries. The composition and properties of drinking water consumed by the population affect the health of the population in general, and the development of the dental system in particular. The undoubted factor that determines the incidence of caries is the level of fluoride in the environment, especially in water.

The study of the effectiveness of fluoride continues for 70 years, and during this time a great deal of scientific and practical experience has been gained, and long-term results have been obtained at the population level. Today it is recognized that it is precisely the entry of optimal fluoride concentrations into the body, especially during the period of teeth formation that significantly affects the prevalence and intensity of dental caries. Numerous clinical studies have confirmed the remineralizing and anticariogenic effect of fluorides, which have a high level of scientific evidence. This level also corresponds to the evidence base on the efficacy and safety of systemic methods of fluoride prophylaxis (fluoridation of water, salt, milk, taking fluoridecontaining tablets and drops), which provide a fairly high anti-caries effect (40-60\%) at a low cost.
\end{abstract}

The results of epidemiological and laboratory studies also indicate that the main role in preventing the occurrence of caries after teething is still local application of fluorides, the anti-caries effect of which is directly proportional to the duration of direct contact of fluoride ions with the surface of the tooth and their concentration in a preventive tool. According to the leading specialists in the field of dentistry, the success of caries prevention on a global scale has provided massive use of fluoride toothpastes for more than 50 years.

Today there are also many other products on the market for using instead of or in addition to fluoride. These include hygiene products containing xylitol, chlorhexidine, and bioactive microcrystals containing hydroxyapatite, zinc, calcium phosphate and other components, as well as preparations for remineralization based on casein-phosphopeptide-amorphous calcium phosphate.

Thus, the use of fluoride-containing oral hygiene products is an effective way to prevent dental caries.
But today, it is relevant to develop and apply fluoride prophylaxis methods among various groups of the population depending on the degree of risk of caries, which will increase the effectiveness of prevention programs.

Keywords: fluorides, fluoride-containing means, dental caries, preventive care, anti-caries effect.

Interrelationship of work with scientific programs, plans, themes. This work is a fragment of the research work of the Department of Dentistry of the Kharkiv National Medical University "Formation and implementation of modern scientific approaches to the diagnosis, treatment and prevention of dental pathology in children and adults", the state registration number 0118 U000939.

Introduction. Dental health of a person is formed from an early childhood and depends on the general body status and on the environmental factors influence $[6,19]$. Causes of an ecological nature play one of the leading roles in the caries incidence. The composition and properties of drinking water consumed affects the health of the population as a whole and the development of the dento-facial system in particular. To the undoubted factors determining the caries prevalence is the fluoride content in the environment, especially in drinking water [5].

However, the role of fluorine in the development of caries is not unambiguous. At low concentrations of this element in drinking water, the prevalence of carious teeth lesions reaches high rates, up to $98-100 \%$ $[21,23]$. The optimum content of fluorine $(0.8-1.2$ $\mathrm{mg} / \mathrm{I})$ contributes to the reduction of morbidity. But an increase in the concentration of fluorine over its optimal values does not cause the expected anticariogenic action $[3,7,11,14]$.

Improvement of methods and means aimed at the onset prevention and treatment of dental caries initial forms is an urgent task of preventive dentistry. Over the last decades, the use of fluoride-containing drugs was recognized as the most popular method of preventing caries in children and adults.

Among the factors that influence the incidence and intensity of dental caries, the intake of optimal concentrations of fluoride by the body, particularly 
during the teeth formation period, is essential $[8,10]$. The study of the fluoride efficacy has lasted for 70 years, and during this time a great scientific and practical experience has been accumulated, and remote results were obtained at the population level. Remineralizing and anti-cariogenic effects of fluorides are confirmed by numerous clinical studies [2, 4, 15], which have a high level of scientific evidence.

This level is also supported by the relevant evidence base for the efficacy and safety of systemic methods for fluoride prophylaxis (fluoridation of water, salt, milk, taking fluoride tablets and drops), which at low cost provide a fairly high anti-cariogenic effect $(40-60 \%)[6,11,30]$. These methods are the most appropriate for use in regions with low socio-economic development and limited access to dental care.

At the same time, the results of numerous epidemiological and laboratory studies indicate that the main role in preventing the onset of caries after teething is played by the local application of fluorides, which anti-cariogenic effect is directly proportional to the duration of direct contact of fluoride ions with the tooth surface and their concentration in the prophylactic drug. According to most leading experts in the field of dentistry, the success of caries prophylaxis on a global scale in recent decades has provided the widespread use of fluoride toothpastes for more than 50 years $[18,20,22]$.

In recent years, many other means designed to be used instead of fluorides or in addition to them have been presented in the market.

Let's consider some of them. Firstly, these are hygiene products containing xylitol, which are sugar substitute products of natural origin. Most often xylitol is included into the chewing gum, sometimes - in other oral hygiene products (toothpastes, oral rinses). Unlike sugars, xylitol can not be a nutritious substrate for plaque bacteria because it breaks the energy metabolism of the main cariogenic species, - Str.mutans.

The use of xylitol chewing gum helps to reduce the transfer of cariogenic bacteria from mother to child and reduces the risk of caries in young children [24, $27,31]$. Perhaps the anti-cariogenic efficacy of these hygiene products is due to stimulating salivation when chewing [26]. Thus, the data on the efficacy of xylitol containing products are highly controversial and the questions about its dosage and frequency of intake remain still unresolved.

Secondly, drugs containing chlorhexidine are broad spectrum antiseptics. They have antibacterial activity against the overwhelming majority of pathogenic microorganisms in the oral cavity and effectively contribute to the reduction of plaque formation. However, with their prolonged use, chlorhexidine containing drugs can cause side effects in the form of changes in the normal microflora composition (dysbiosis), coloration of the teeth and tongue surface, taste sensations disturbance. Data on the efficient use of solutions, varnishes and gels with chlorhexidine for prevention of caries are also quite controversial and it may be reasonable to use them only to prevent caries fissure during the permanent teeth eruption. Thus, according to Twetman S. (2004), the evident cariestatic effect of chlorhexidine-based varnish applications in children and adolescents with high caries risk unfortunately was not detected. In this regard, the use of chlorhexidine as a supplement to fluorides in people with poor oral hygiene can be considered more correct.

The third group of local prophylaxis contains case in phosphopeptide-amorphous calcium phosphate (CPP-ACP (Recaldent TM, Colgate, USA), which is a modern means for remineralization of initial carious lesions. Due to its adhesiveness, case in phosphopeptide is fixed on the tooth surface and is capable of transporting calcium ions and phosphate into the surface layers of the tooth enamel. The advantage of this system is maintenance of calcium phosphate in an amorphous state, which makes it bioavailable at neutral $\mathrm{pH}$ values. However, the quantity and quality of the currently available clinical studies do not permit to convincingly confirm the advantages of Recaldent TM compared to fluoride preparations for remineralization of enamel $[12,16,17]$.

And, finally, the fourth group consists of oral hygiene products with bioactive microcrystals containing hydroxyapatite, zinc, calcium phosphate and other components, which, according to manufacturers, fill the micro-damage of enamel for a long time, in contrast to fluorides that have only superficial effect. However, such statements, unfortunately, are also deprived of evidence: literature sources do not include descriptions that compare the efficacy of these fluoridated toothpastes.

Thus, as of today, the most studied are local fluoride containing drugs that provide anti-cariogenic and remineralizing effect, which efficacy is proved by the results of numerous clinical studies performed in compliance with the standards of the evidence-based medicine. That is why fluorides are widely used as the main means for preventing teeth caries. But are they safe for health? In the list of hazardous substances, the fluoride ion is classified as hazard class I with its high content in the soil and up to class II in water. Regular intake of high fluoride doses by the body leads to the development of dental fluorosis, and the intake of $12-14 \mathrm{mg}$ of fluoride per day affects the bone skeleton. Acute intoxication can develop when taking $1 \mathrm{mg}$ of fluoride per $1 \mathrm{~kg}$ of body weight. At the same time, the influence of high fluoride concentration on the course of pregnancy and health of the newborn 
was not detected; there was no association established with genetic disorders, malignant tumors and other severe pathologies in adults and children [13]. In the United States, where fluoridation of water is a common method of preventing dental caries, weak forms of fluorosis are found in $26 \%$ of 9 -year-old children and in $19 \%$ of 17 -year-old adolescents, while moderate and severe forms are diagnosed quite rarely - in $1.1 \%$ and $0.3 \%$ of cases respectively. In most areas of Ukraine, the incidence of fluorosis in children and adolescents does not exceed 4-5\%, and with optimum and high content of fluoride, it reaches $31 \%-34 \%$, with the prevalence of very weak and weak forms of lesions, which are manifested in slight cosmetic defects and do not damage the dental health With the use of fluoride-containing drugs in young children, the risk of developing fluorosis increases by $30 \%$, however, with a high probability of caries onset, advantages of their use prevail. However, it is advisable to adhere to the recommended dosage [29]. To achieve maximum efficacy and safety of fluorine compounds, it is necessary:

- to know the concentration of fluoride in the drinking water of the region: if it is lower than the optimal rate, it is possible to use fluoride additives, but if it is exceeding 2 ppm, children need to use water from alternative sources of water supply;

- to use fluorides regularly at low concentrations (toothbrush cleaning twice a day with fluorinecontaining paste);

- for children under 6 years of age, to clean teeth, the amount of fluoride toothpaste should not exceed the size of a nut $(0.25 \mathrm{~g})$;

- not to use additional sources of fluoride (including fluoride-based rinsing agents) in preschool children without consulting a dentist.

Thus, when administering fluoride-containing prophylaxis, it is necessary to assess the risk of dental caries development in a patient. Several assessment criteria are currently suggested. So, in the US, a system has been developed to assess the risk of caries in children under 6 years of age and in those from 6 to 18 years of age through their examination and questionnaires. It involves identification of risk factors (dental plaque, deep fissures and pits), caries indicators (caries cavities detected by radiography, caries on the approximal teeth surfaces, foci of enamel demineralization) and protective factors (use of fluoride and remineralizing drugs) [21].

In determining one of the caries indicators, the patient is classified as a high risk group, and in the case of identifying risk factors as a moderate risk group of teeth caries development. Recent recommendations for the use of fluorides in children, developed by EADP (European Archives of Pediatric Dentistry, 2009), take into account the child's age and the risk of caries. According to contemporary views, the cariestatic effect of fluorine is more pronounced in its local application than with systemic use [24]. Experts believe that the ideal method for raising the dental health level of the population is the use of fluorinated toothpastes for the reason that this method is convenient, inexpensive, efficient and widespread [22].

There exists an opinion that the use of children's low-fluoride toothpastes (500 ppm) due to their lack of efficacy is ungrounded [25, 28, 30]. European dentists believe that this fluoride concentration is only acceptable in the toothpaste for infants (from 6 months to 2 years). For children from 2 to 6 years of age, it is advisable to use toothpaste containing 1000 ppm of fluoride (in the amount of a pea size) twice a day, and starting with 6 years - from 1450 ppm of fluoride and more. At high risk of dental caries, professional and regular remineralizing therapy is recommended.

At high risk of dental caries, it is recommended to carry out local exogenous prophylaxis, as one of the "Duraphat TM" varnish advantages is the simplicity and ease of use, as it does not require prior professional oral hygiene and drying of the tooth surface. We widely use prophylactic fluoride-based "Ftoroplen" varnish (Latus, Ukraine) and the salt system for deep fluoridation of enamel "Ftorcalcit-E" (Latus, Ukraine). The "Duraphat" Varnish (Colgate, USA) contains $2.26 \%$ of fluoride, "Fluor Protector" varnishes (Ivoclar Vivadent, Liechtenstein) $-0.1 \%$ of fluoride and "Compose-al" (Dentamerica, USA) includes sodium fluoride and calcium fluoride. "Ftorlak" (Stoma, Ukraine) contains $5 \%$ of sodium fluoride and is prepared on the basis of cedar or fir balsam. The use of varnishes should be recommended at moderate or high levels of caries intensity in the population, to children and young people at high risk of developing caries. The frequency of applying varnish is $2-4$ times a year, depending on the activity of the caries.

Fluoride solutions and gels for professional use: dental clinics use drugs with a sufficiently high concentration of sodium fluoride: $2 \%$ solution of sodium fluoride; sodium fluoride, acidified with phosphoric acid (APF) in the form of a solution and gel $(1.23 \%$ fluoride concentration); solutions and gels containing tin fluoride or aminofluoride. The indicated solutions and gels can be used in children in the form of gargles and applications 1-2 times a year.

However, despite the proven efficacy of professional fluoride-containing drugs, in our country, their active use with a prophylactic purpose is observed predominantly in pediatric dental practice, and the opinion prevails among experts about the futility of using of fluorides in the adult population.

According to the results of the literature data review, the following conclusions should be made: 
- the use of fluoride-containing oral hygiene products is an efficient way of preventing dental caries that has the highest level of reliability in evidence-based medicine;

- the use of fluorides should be considered as a "method of choice" to prevent the development of caries both in the dental clinic and at home;

- the use of highly concentrated fluorinecontaining agents (varnishes, gels) is most effective for patients with moderate to high risk of developing caries;

- as of today, the urgent task is development and application of fluoride prophylaxis methods among different groups of the population depending on the degree of caries risk, which will raise the efficacy of prevention programs.

\section{References}

1. Belousov YuN, Pozdnyakova YuV, Botezatu KYu, i dr. Rol' ftora v profilaktike kariyesa u detey. Sovremennaya meditsina: aktual'nyye voprosy: sb st po mater II mezhdunar nauch-prakt konf. Chast' II. Novosibirsk; 2011. 2011: 31-3. [Russian]

2. Hrokhivs'kyy VN, Den'ha OV. Profilaktyka ta likuvannya urazhen' tverdykh tkanyn zubiv u rehionakh z pidvyshchenym vmistom ftoru v pytniy void. Profilaktychna ta dytyacha stomatolohiya. 2016; 2(15): 16-20. [Ukrainian]

3. Danilevskiy NF, Khomenko LA, Ostapko Yel. Shkol'naya obrazovatel'naya programma profilaktiki stomatologicheskikh zabolevaniy v UKraine: 5 let uspeshnoy raboty. Sovremennaya stomatologiya. 2002; 4: 104-6. [Russian]

4. Den'ga OV, Den'ga EM. Integral'naya ekspress-otsenka urovnya funktsional'nykh reaktsiy v polosti rta u detey. Vísnik stomatologií. 2003; 5 (Spets vip.): 130-48. [Russian]

5. Kas'kova LF, Amosova LI, Karpenko OO, ta in. Profilaktyka stomatolohichnykh zakhvoryuvan': pidruch dlya stud vyshchykh med navch zakl. Kharkiv; 2011. 392 p. [Ukrainian]

6. Knappvest A. Profilaktika i lecheniye kariyesa vremennykh zubov metodom glubokogo ftorirovaniya. Detskaya stomatologiya. 2000; 21. [Russian]

7. Kuz'mina EM, Kuz'mina IN, Petrina YeS. Stomatologicheskaya zabolevayemost' naseleniya. Sostoyaniye tkaney parodonta i slizistoy obolochki rta. Pod red prof Yanushevicha OO. M; 2009. 236 p. [Russian]

8. Kuryakina NV. Terapevticheskaya stomatologiya detskogo vozrasta. M: Meditsina, N Novgorod: NGMA; 2001. p. 15873. [Russian]

9. Kuryakina NV, Savel'yeva NA. Stomatologiya profilakticheskaya (rukovodstvo po pervichnoy profilaktike stomatologicheskikh zabolevaniy). N. Novgorod; 2005. 284 p. [Russian]

10. Leus PA. Profilakticheskaya kommunal'naya stomatologiya. M: Meditsinskaya kniga; 2008. 444 p. [Russian]

11. Marchuk NV. Suchasni pidkhody do systemy profilaktyky u spektri simeynoyi medytsyny. Bukovyns'kyy medychnyy visnyk. 2005; 3(9): 154-7. [Ukrainian]

12. Moskalenko VF, Yavorskyy OP, Parpaley IO. Profilaktychna medytsyna - problemy ta perspekty vy rozvytku. Naukovyy visnyk Natsional'noho medychnoho universytetu imeni OO Bohomol'tsya. 2004; 1-2; 69-73. [Ukrainian]

13. Nikolishin AK. Sovremennyy vzglyad na sostoyaniye tverdykh tkaney zuba pri razlichnoy stepeni flyuoroza. Ukraïns'kiy stomatologíchniy al'manakh. 2002; 6: 52-4. [Russian]

14. Popovych ZB, Rozhko MM, Kindrat HV, ta in. Analiz struktury stomatolohichnoyi zakhvoryuvanosti u ditey, yaki prozhyvayut' na ekolohichno zabrudnenykh terytoriyakh. Novyny stomatolohiyi. 2018; 3: 84-6. [Ukrainian]

15. Smolyar NI, Solon'ko GM, Bezvushko EV, i dr. Vliyaniye remineralizuyushchikh preparatov na sozrevaniye emali $v$ oblasti fissur postoyannykh zubov u detey. Sovremennaya stomatologiya. 2006; 3: 69-71. [Russian]

16. Uvarenko AR. Vyrishennya problemy yakosti medychnoho zabezpechennya spivvitchyznykiv lezhyt' nasampered $u$ ploshchyni profilaktyky. Okhorona zdorov'ya Ukrayiny. 2005; 1-2: 18-22. [Ukrainian]

17. Khamadeyeva AM, Burda GK, Burda AG. Opyt vnedreniya programmy profilaktiki osnovnykh stomatologicheskikh zabolevaniy u detey, rezervy povysheniya yeye effektivnosti. Novoye $v$ stomatologii. 2002; 7: 42-3. [Russian]

18. Khamadayeva AM, Litvinov SD. My i ftorsoderzhashchiye zubnyye pasty. Stomatologiya dlya vsekh. 2005; 2: 32-3. [Russian]

19. Khomenko LA. Terapevticheskaya stomatologiya detskogo vozrasta. Kyiv; 2007. 815 p. [Russian]

20. Yurgina OK. Kakoy sostav dolzhny imet' detskiye zubnyye pasty? Stomatolog-praktik. 2011; 4: 57-9. [Russian]

21. Lussi A, Hellwig E, Klimek J. Fluoride: mechanism of action and recommendations for use. Swiss Dent J SSO. 2012; 11: 1037-42.

22. Bratthall D, Hansel-Petersson G, Sundberg H. Reasons for the caries decline: what do the experts believe? Eur J Oral Sci. 1996; 104: 416-22. PMID: 8930592. https://doi.org/10.1111/j.1600-0722.1996.tb00104.x

23. Burt BA. Prevention policies in the light of the changed distribution of dental caries. Acta Odontol Scand. 1998; 3 (56): 179-86. PMID: 9688230. https://doi.org/10.1080/000163598422956

24. Deshpande A, Jadad AR. The impact of polyol-containing chewing gums on dental caries: a systematic review of original randomized controlled trials and observational studies. J Am Denr Assoc. 2008; 12(139): 1602-14. PMID: 19047666. https://doi.org/10.14219/jada.archive.2008.0102 
25. Ismail Al, Hasson H. Fluoride supplements, dental caries and fluorosis: a systematic review. J Am Denr Assoc. 2008; 11(139): 1457-68. PMID: 18978383. https://doi.org/10.14219/jada.archive.2008.0071

26. Lingstrem P, Moynihan P. Nutrition, saliva, and oral health. Nutrition. 2003; 6(19): 567-9. PMID: 12781864. https:// doi.org/10.1016/S0899-9007(03)00062-5

27. Nakai $Y$, Shinga-Ishihara C, Kaji M, Moriya K, Murakami-Yamanaka K, Takimura M. Xylitol gum and maternal transmission of mutans streptococci. J Dent Res. 2010; 1(89): 56-60. PMID: 19948944. DOI: 10.1177/0022034509352958

28. Steiner M, Helfenstein U, Menghini G. Effect of 1000 ppm relative to 250 ppm fluoride toothpaste. A metaanalysis. Am J Dent. 2004; 2(17): 85-8. PMID: 15151332

29. Twetman S. Antimicrobials in future caries control? A review with special reference to chlorhexidine treatment. Caries Res. 2004; 3(38): 223-9. PMID: 15153692. DOI: 10.1159/000077758

30. Twetman S, Axelsson S, Dahlgren H, Holm AK, Källestål C, Lagerlöf F, et al. Caries-preventive effect of fluoride toothpaste: a systematic review. Acta Odontol Scand. 2003; 6(61): 347-55. PMID: 14960006. https:// doi.org/10.1080/00016350310007590

31. Twetman S. Consistent evidence to support the use of xylitol- and sorbitol-containing chewing gum to prevent dental caries. Evid Based Dent. 2009; 1(10): 10-1. PMID: 19322219. DOI: 10.1038/sj.ebd.6400626

32. Yeung CA. A systematic review of the efficacy and safety of fluoridation. Evid Based Dent. 2008; 2(9): 39-43. PMID: 18584000. DOI: $10.1038 /$ sj.ebd. 6400578

\section{УДК 616. 314-002-08-039. 71}

\section{ДЕЯКІ АСПЕКТИ ПРОФІЛАКТИКИ КАРІЄСА ЗУБІВ}

\section{Соколова І. І., Ярошенко О. Г., Олейнічук В. В.}

Резюме. Екологічні чинники відіграють одну з провідних ролей у захворюваності на карієс. Склад и властивості питної води, яку вживає населення, впливають на здоров'я популяції в цілому та на розвиток зубощелепної системи зокрема. До безсумнівних факторів, які визначають ураженість карієсом, належить рівень вмісту фтору в зовнішньому середовищі, особливо в питній воді.

Вивчення ефективності фторидів триває протягом 70 років, і за цей час був накопичений великий науковий і практичний досвід, отримані віддалені результати на популяційному рівні. Сьогодні $€$ визнаною думка, що саме надходження в організм оптимальних концентрацій фториду, особливо в період формування зубів, суттєво впливають на поширеність і інтенсивність карієсу зубів. Численними клінічними дослідженнями підтверджено реминералізуючу та протикаріозну дію фрторидів, які мають високий рівень наукової доказовості. Цьому рівню відповідає й доказова база щодо ефективності й безпеки системних методів фрторидної профрілактики (фрторування води, солі, молока, прийому фрторвмісних пігулок і крапель), які при низькій вартості забезпечують досить високий протикаріозний ефект (40-60\%).

Також результати епідеміологічних і лабораторних досліджень свідчать, що головну роль у попередженні виникнення карієсу після прорізування зубів відіграє все ж таки місцеве застосування фторидів, протикаріозний ефект яких є прямо пропорційний тривалості безпосереднього контакту іонів фтору з поверхнею зуба та їхній концентрації в профілактичному засобі. На думку більшості провідних фахівців в області стоматології, успіх профрілактики карієсу в глобальному масштабі останніми десятиліттями забезпечило масове використання фторвмісних зубних паст протягом більш ніж 50 років.

Останніми роками на ринку також представлено безліч інших засобів для використання замість фрторидів або на додаток до них. До таких належать засоби гігієни, що містять ксиліт, хлоргексидин, біоактивні мікрокристали із вмістом гідроксиапатиту, цинку, фоссрату кальцію та інших компонентів, а також препарати для ремінералізації на основі казеінфосфопептід-аморфного фосфрату кальцію.

Отже, використання фторвмісних засобів гігієни порожнини рота є ефективним способом профрілактики карієсу зубів. Але на сьогоднішній день нагальним є розробка й застосування методів фторидної профрілактики серед різних груп населення в залежності від ступеня ризику виникнення карієсу, що дозволить підвищити ефективність профілактичних програм.

Ключові слова: фрториди, фторвмісні засоби, карієс зубів, профілактичні заходи, протикаріозний есрект.

УДК 616. 314-002-08-039. 71

\section{НЕКОТОРЫЕ АСПЕКТЫ ПРОФИЛАКТИКИ КАРИЕСА ЗУБОВ}

Соколова И. И., Ярошенко Е. Г., Олейничук В. В.

Резюме. Экологические факторы играют одну из ведущих ролей в заболеваемости кариесом. Состав и свойства питьевой воды, которую употребляет населения, влияют на здоровье популяции в целом, и на развитие зубочелюстной системы в частности. К несомненным фракторам, определяющим пораженность кариесом, относится уровень содержания фтора во внешней среде, особенно в воде. 
Изучение эфффективности фторидов продолжается в течение 70 лет, и за это время был накоплен большой научный и практический опыт, получены отдаленные результаты на популяционном уровне. Сегодня признано мнение, что именно поступление в организм оптимальных концентраций фторида, особенно в период формирования зубов, существенно влияет на распространенность и интенсивность кариеса зубов. Многочисленными клиническими исследованиями подтверждено реминерализирующее и противокариозное действие фторидов, которые имеют высокий уровень научной доказательности. Этому уровню соответствует и доказательная база по эффективности и безопасности системных методов фторидной профилактики (фторирование воды, соли, молока, приема фторсодержащих таблеток и капель), которые при низкой стоимости обеспечивают достаточно высокий противокариозный эффект (40-60\%).

Также результаты эпидемиологических и лабораторных исследований свидетельствуют, что главную роль в предупреждении возникновения кариеса после прорезывания зубов играет все же местное применение фторидов, противокариозный эффрект которых прямо пропорционален длительности непосредственного контакта ионов фтора с поверхностью зуба и их концентрации в профилактическом средстве. По мнению большинства ведущих специалистов в области стоматологии, успех профилактики кариеса в глобальном масштабе обеспечило массовое использование фторсодержащих зубных паст в течение более чем 50 лет.

В последние годы на рынке также представлено множество других средств для использования вместо фторидов или в дополнение к ним. К таковым относятся средства гигиены, содержащие ксилит, хлоргексидин, биоактивные микрокристаллы с содержанием гидроксиапатита, цинка, фоссрата кальция и других компонентов, а также препараты для реминерализации на основе казеинфосфопептид-аморфного фоссфата кальция.

Таким образом, использование фторсодержащих средств гигиены полости рта является эффективным способом профилактики кариеса зубов. Но на сегодняшний день актуальным является разработка и применение методов фрторидной профилактики среди различных групп населения в зависимости от степени риска возникновения кариеса, что позволит повысить эффективность профилактических программ.

Ключевые слова: фториды, фрторсодержащие средства, кариес зубов, профилактические мероприятия, противокариозный эфффект.

The authors of this study confirm that the research and publication of the results were not associated with any conflicts regarding commercial or financial relations, relations with organizations and/or individuals who may have been related to the study, and interrelations of coauthors of the article.

Стаття надійшла 30.03.2019 р. Рекомендована до друку на засіданні редакційної колеаії після рецензування 